\title{
Aplikované tělocvičné aktivity žáků s dětskou mozkovou obrnou
}

\section{Physical Activities Applied to Pupils with Cerebral Palsy}

\author{
Miroslava Spurná, Martin Kudláček
}

Fakulta tělesné kultury Univerzity Palackého v Olomouci, Česká republika

\begin{abstract}
Abstrakt
Pravidelná a optimální tělocvičná aktivita predstavuje především jeden z predpokladů pro získání a udržení tělesné a duševní kondice člověka. U žáků s tělesným postižením (TP) jsou vhodně zvolené tělocvičné aktivity (TA) navíc považovány za velmi účelný prostředek socializace a integrace těchto žáků do intaktní populace. O významu TA a jejich realizaci v rámci tělesné výchovy se v poslední době můžeme dočíst přvevážně v kontextu problematiky integrace žáku s TP do běžných škol. O podobě tělesné výchovy a TA žákủ navštěvujicích speciálni školy se ale v naší speciálně pedagogické literatuře můžeme dočist jen velmi málo. Cílem studie, která je prezentována v tomto článku, je popsat současný stav participace žáků s TP v TA a poukázat na možnou podobu a způsob realizace TA těchto žákủ. Cílovou skupinou byli žáci s dětskou mozkovou obrnou (DMO) navštěvující základní školu speciální pro žáky s postižením více vadami v Olomouci. Z výsledků je patrný význam organizovaných forem TA jako je tělesná výchova a školni sportovní kroužky, které u většiny žáků predstavují jediné TA v prüběhu celého dne. Dalšimi faktory výrazně ovlivňujícími míru participace žáků v TA je úroveň motoriky žákủ, př́istup rodiny $k$ TA a informovanost žáka $v$ oblasti TA. $Z$ těchto aspektů je potřeba vycházet při plánování a realizaci $T A$ žáků $S T P$.
\end{abstract}

\begin{abstract}
Regular and optimum activity is primarily one of the preconditions for obtaining and maintaining human's physical and mental condition. For pupils with physical disabilities are suitably chosen gym activity also considered a suitable means of socialization and integration of pupils into the intact population. The importance of physical education and its implementation in the context of physical education in recent times we read mostly in the context of issues of integration of pupils with disabilities into mainstream schools. There are not so many special educational books which are dealt with the shape of physical education and pupils in special schools. The main aim of this article is to describe the current status of participation of students with physical disability in the physical education and show the possible form and method of the gyms activity these students. The target group was students with cerebral palsy attending primary school for students with multiple disabilities in Olomouc. The results illustrate the importance of institutional forms of gyms activities such as physical education and school sports clubs, which are for most students the only physical activities throughout the day. Other factors significantly affecting the rate of participation of pupils are level of pupils' motorical skills, family approach to the physical activities and pupils' access to informations in the physical activities field. These aspects must by taken as the basis for planning and implementation of gyms activities pupils with physical disabilities.
\end{abstract}

Klíčová slova: aplikované pohybové aktivity, tělesné postižení, dětská mozková obrna, aplikovaná tělesná výchova, volný čas

Keywords: $\quad$ Adapted Physical Aktivity, physical disability, cerebral palsy, Adapted Physical Education, leisure time

Studie vznikla za podpory výzkumného zámèru FTK UP v Olomouci Pohybová aktivita a inaktivita obyvatel České republiky v důsledku behaviorálních změn. No. 6198959221 


\section{ÚVOD}

Tělesný pohyb je neodmyslitelně spojen s životem člověka a jeho vývojem. Kalvach et al. (2004) uvádí, že dostatečný tělesný pohyb umožňuje zachování potřebné odolnosti a adaptace organizmu na různé vnější podmínky, jako je tělesná zátěž, a zvyšuje i jeho psychickou odolnost. Snížení každodenní potřebné dávky tělesného pohybu na minimum má nepříznivý dopad na fyzickou a psychickou zdatnost. $\mathrm{Z}$ těchto důvodů je důležité zaměřit pozornost na správný pohybový režim a pravidelné tělocvičné aktivity každého jedince. Hovoříme-li zde o tělocvičných aktivitách (TA), máme na mysli specifické pohybové aktivity, jejichž obsahem jsou záměrná tělesná cvičení. Tato cvičení mohou probíhat v podobě tělesné výchovy, sportu nebo volnočasové tělocvičné činnosti (tělocvičné rekreace).

Osoby s TP představují velmi heterogenní skupinu, jejímž společným znakem je celkové nebo částečné omezení hybnosti. TP ovšem nelze považovat jen za odchylku tělesnou, ale pro jeho komplexní pojetí je nutné zohledňovat i jeho sociální aspekty. Celistvé pojetí tělesného postižení ve vztahu k osobnosti jedince s postižením je vyjádřeno v klasifikaci postižení WHO ICF 2001 (International Classification of Functioning, Disability and Health). Postižení zde zahrnuje narušení fungování na úrovni poruchy (impairment), aktivity (activity limitation) nebo participace (participation restriction). Poruchou jsou zde vyjádřeny problémy na úrovni tělesných funkcí či struktur, jako je výrazná deviace nebo ztráta. Aktivitou chápeme úroveň pohybových schopností či jednání osoby a zapojení osoby v životních situacích (World Health Organisation, 2009). Tělesné postižení lze tedy chápat jako tělesné nápadnosti či snížení úrovně pohybové schopnosti s dlouhodobým nebo podstatným působením na kognitivní, emocionální a sociální výkony (Renotiérová, 2006). Jeden z předpokladů pro harmonický rozvoj člověka je pravidelná a optimální TA. U žáků s TP se u vhodných TA klade důraz především na jejich význam socializační a integrační. Pomocí vhodně vedených TA je možné prožít úspěch a řadu pozitivních pocitů, které působí na zvýšení sebehodnocení a celkového sebepojetí jedince (Čurdová, 2005). Vliv TA na sebepojetí osob s TP si lze názorně představit na modelu sportovního umocnění (obr. č. 1).

Obr. č. 1: Model sportovního umocnění (Sherrill in: Kudláček, 2007).

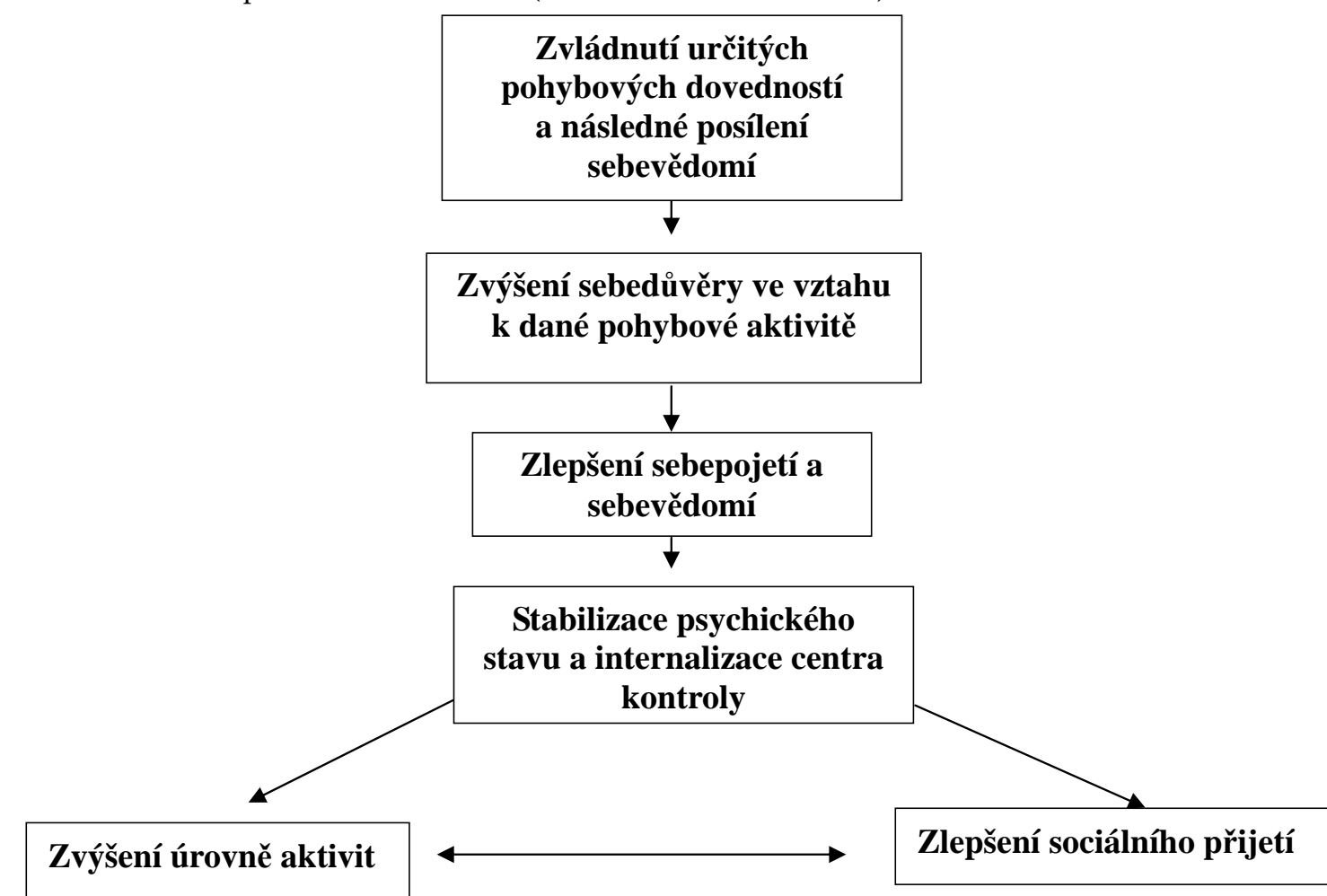


Proces umocnění začíná zvládnutím určitých dovedností (aktivit), které se projevují ve zvýšení sebevědomí a zlepšení sebepojetí osob $\mathrm{s}$ TP. To vše napomáhá k vytvoření určité psychické rovnováhy a pocitu, že jedinec s TP má tzv. kontrolu nad svým životem. Důsledkem toho všeho je snazší začlenění do širší společnosti a větší odvaha zkoušet nové aktivity. Tento model lze samozřejmě aplikovat i na širši pojetí pohybových aktivit zahrnující úkony každodenního života. Prostřednictvím TA se otevírá cesta ke snazší komunikaci mezi lidmi a sociálními skupinami, a tím současně i k nenásilnému začlenění osob s TP do těchto skupin (Machová, 2008; Kyralová in: Kudláček, 2007).

Problematika tělocvičných aktivit osob se specifickými potřebami spadá do oblasti aplikovaných pohybových aktivit (APA). APA představují zastřešující termín pro všechny služby podporující aktivní zdravý životní styl osob se specifickými potřebami prostřednictvím TA. Za hlavní cíl přitom považuje zajistit všem těmto osobám úspěšnou účast v TA formou aktivit přizpůsobených nebo nově vytvořených, a to vždy v souladu se zájmy a schopnostmi každého jedince (Válková \& Morisbak, 2006). Při realizaci TA osob s postižením vycházíme zejména z individuality jedince (věk, druh a stupeň postižení, zájmy apod.), z charakteristiky TA, kterou chceme přizpůsobovat, a ze znalosti adaptačních strategií daného prostředí. Cíle a úkoly APA je možné realizovat prostřednictvím aplikované tělesné výchovy (ATV), sportu pro osoby se specifickými potřebami a tělocvičné rekreace osob se specifickými potřebami. Teoretické a praktické kompetence potřebné $\mathrm{k}$ působení $\mathrm{v}$ oblasti APA lze získat $\mathrm{v}$ rámci studijních oborů Aplikovaná tělesná výchova a nově i Aplikované pohybové aktivity. V současné době je u nás možné tyto obory studovat pouze na Fakultě tělesné kultury Univerzity Palackého v Olomouci (více na www. apa.upol.cz).

Konkrétněji si lze principy APA představit na specifické skupině žáků s dětskou mozkovou obrnou (DMO). U žáků s tímto postižením se projevují poruchy nejen v oblasti motorické, ale ve většině případů se u jedinců s DMO vyskytují také mentální retardace různého stupně, nezř́ídka jsou přidružena i další onemocnění a komplikace jako jsou epileptické záchvaty, smyslové vady a poruchy řeči. Přesto se žáci s DMO mohou účastnit všech forem TA od tělesné výchovy přes tělocvičnou rekreaci ve volném čase až po TA na sportovní úrovni. Ne vždy tento názor panoval jak v odborné teorii, tak zejména v praxi. Žáci s DMO a dalšími poruchami hybnosti podobných projevů jsou často „uvolňováni“ z tělesné výchovy a jiných podob TA. Tento fakt většinou vychází z obav z nevhodného vlivu TA na zdravotní stav jedince. Jako další a velmi časté faktory limitující zapojení žáků s TP (DMO) do TA jsou uváděny limity materiální (nedostatečné prostorové podmínky, nevhodné kompenzační pomůcky a sportovní vybavení apod.) a limity personální (nedostatečná připravenost učitelů tělesné výchovy v oblasti APA, neexistence konzultantů ATV, nedostatek asistentů pedagoga) (Kudláček, 2008; Kudláček, Ješina, Štěrbová, 2008). Obdobně k TA žáků s DMO přistupují i samotní rodiče. Čurdová (2002) k tomu dodává, že nejčastější př́činou, proč rodiče nepodněcují své dítě $\mathrm{k}$ TA ve volném čase, je vedle nedostatku informací o možnostech TA osob s DMO také časově náročné zaměstnání, nedostatek volného času či komplikovaná a časově náročná péče o dítě s DMO. Častým jevem je také zaměňování rehabilitačního cvičení v rámci fyzioterapeutické péče za TA sportovního či rekreačního typu, mající na rozdíl od rehabilitačních cvičení výrazně prožitkový a socializační charakter.

Podoba vhodných TA osob s DMO se utváří především na základě individuálních zvláštností každého jedince (věk, stupeň postižení, zájmy a potřeby jedince, možnosti rodiny apod.). Při organizaci jakýchkoliv TA žáků s DMO, at už na školní, rekreační či závodní úrovni, je dobré vycházet z písemně potvrzených informací o zdravotním stavu jednotlivců. Na základě těchto informací můžeme plánovat a modifikovat TA a současně předcházet př́ípadným zdravotním komplikacím spojených s DMO (např. epilepsie). Jako vhodná se jeví i spolupráce s fyzioterapeutem, ke kterému žák dochází, jehož prostřednictvím je možné získat cenné rady vztahující se k individuálním pohybovým možnostem žáka s DMO a kontraindikacím daného cvičení (Wittmanová, 2007). K hlavním aspektům, které je nutné zohlednit při realizaci TA osob s DMO, patř́i a) úroveň mobility (využití speciálních pomůcek, zajištění asistence, různé způsoby provedení dané TA), b) snazší unavitelnost a c) faktory zvyšující spasticitu jedince (např. pocit strachu, rozrušení z leknutí, náhlé hlasité zvuky, únava apod.) (Molik, 2006). V rámci př́ípravy TA žáků s DMO vycházíme nejen $z$ individuality daného žáka a jeho potřeb, ale také především $z$ charakteru zvolené TA. 
Každý realizátor APA by měl bezpodmínečně znát cíl a smysl TA. Bez toho není možné TA upravit tak, aby se nenarušila její vlastní podstata. Vhodná úprava TA pro žáky s DMO souvisí se znalostí adaptačních strategií, které zahrnují úpravu prostředí, pomůcek a pravidel. TA tak mohou být modifikovány různými způsoby. Jedním $\mathrm{z}$ nich je úprava pravidel, pomůcek či prostředí tak, aby se TA mohli účastnit všichni žáci s různou úrovní pohybových schopností (např. při basketbalu snížíme nebo zvětšíme koše). Př́padně je možné upravit podmínky TA, které budou platit pouze pro žáky s omezenými pohybovými schopnostmi tak, aby znevýhodňovaly ostatní účastníky dané aktivity (např. volejbal může být hrán jedním hráčem jako přehazovaná či může používat jiný způsob podání, přihrávek i nahrávek apod.). Tak TA mohou umožnit zapojovat žáka s postižením do společných aktivit s žáky s jinou úrovní pohybových schopností, aniž by byla kterákoliv strana znevýhodněna. Další modifikované TA mohou mít podobu speciálních TA, které jsou od samého počátku určeny a uzpůsobeny pro daný typ tělesného postižení (boccia, polybat, basketbal na vozíku apod.).

Zastřešující organizací pro sportovce s DMO je Cerebral Palsy International Sports and Recreation Association (CP-ISRA), což je světová organizace pro osoby s centrální poruchou hybnosti a př́buznými neurologickými stavy. Tato organizace sdružuje a hájí práva všech mezinárodních a národních organizací pracujících s osobami s centrální poruchou hybnosti. CP-ISRA je v České republice zastoupena Českou federací sportovců s centrálními poruchami hybnosti (ČFSCPH) neboli Spastic Handicap. Pod organizaci Spastik Handicap spadá 12 TJ a SK, jejichž prostřednictvím je podporováno a realizováno 12 sportovních disciplín (boccia, kuželky, závěsný kuželník, atletika, plavání, lyžování, stolní tenis, vodní turistika, lukostřelba, kopaná, cyklistika a šachy), kterých se účastní sportovci s DMO na základě sportovní funkční klasifikace (CP1-CP8) (Česká federace sportovců s centrálními poruchami hybnosti Spastic Handicap, 2009). V těchto sportovních disciplínách se mohou sportovci s DMO realizovat v rámci národních či mezinárodních soutěží a paralympiády.

Jednou z oblastí každodenního života, která nabízí prostor pro realizaci TA, je i oblast volného času. Volný čas chápeme především jako část doby, kterou má každý pro sebe a s níž může disponovat podle svého vlastního uvážení. Do jaké míry ovšem můžeme hovořit o svobodném rozhodování o podobě volného času u osob s DMO? Jejich výběr volnočasových aktivit závisí převážně na úrovni vlastní motoriky, a tedy $\mathrm{z}$ větší části i na pomoci jejich sociálního okolí (asistenti, práátelé, sourozenci, rodiče apod.). Dalši otázkou je, jakými činnostmi tráví žáci s DMO volný čas. Zde je důležité dodat, že umět kvalitně prožít volný čas se každý z nás musí naučit. Zvláště velký důraz by se měl klást na kvalitní a smysluplnou náplň volného času u dětí a mládeže, nebot’ u této věkové skupiny sehrává volný čas významnou úlohu v procesu jejich socializace a také v celkovém vývoji osobnosti (Hroncová, 2000). Podstatnou roli ve volbě a realizaci volnočasových aktivit žáka s DMO hrají především způsob, jakým tráví volný čas rodina žáka, a také výchovně vzdělávací působení školy. Hovoříme-li o vhodných volnočasových aktivitách v kontextu TA žáků s DMO, je důležité, aby obě tyto instituce byly vhodným vzorem a vedly žáky s DMO k pěstování kladného vztahu k TA. Kladný vztah k TA může sloužit jako základní stavební kámen pro volbu způsobu trávení volného času. Mezi hlavní překážky, se kterými se můžeme setkat při realizaci TA žáků s DMO ve volném čase, patř́ materiální a technické podmínky, malá informovanost o možnostech volnočasových TA i vlastní úroveň nabídek volnočasových TA pro žáky s DMO. Další možnou překážkou pro trávení volného času prostř̌ednictvím TA bývá u žáků s DMO úroveň jejich mobility a s tím spojený pocit kompetentnosti $\mathrm{k}$ dané TA.

Cílem následující studie bylo popsat současný stav participace žáků ZŠ pro žáky s vícenásobným postižením v tělocvičných aktivitách.

\section{METODIKA}

\section{Participanti}

Studie se účastnili žáci ZŠ a SŠ Credo Olomouc, o.p.s., kteří splňovali následující kritéria: a) žák s diagnózou DMO (spastická forma diparetická a kvadruparetická), b) věk 12-14 let, c) IQ 70 a vyšší. Diagnóza DMO a výše IQ byla ověřována ze zdravotní dokumentace žáků ve spolupráci s jeho fyzioterapeutem a ředitelem školy. Skupinu žáků odpovídajících našim kritériím představuje 15 dětí, z nichž 11 (73\%) bylo 
ochotno s námi spolupracovat. Výzkumný soubor tedy představuje 11 žáků, z nichž 5 spadá do skupiny „chodící“ a 6 do skupiny „vozíčkáři“. Charakteristika členů jednotlivých skupin je následující: 1) Chodící - lehká až střední diparetická forma DMO. Jsou schopni samostatné chůze, př́ípadně k chůzi využívají kompenzačních pomůcek jako jsou berle či francouzské hole. Jsou schopni samostatné sebeobsluhy; 2) Vozičkáři - lehká až střední kvadruparetická forma DMO. Ke každodenním aktivitám využívají mechanický vozík, který jsou schopni samostatně pohánět. K sebeobsluze vyžadují asistenci druhých osob.

\section{Názory participantů na školní TA}

Pro zjištování názorů participantů na TA nabízené prostřednictvím školní tělesné výchovy (TV) a školních sportovních kroužků byla použita metoda semistrukurovaného rozhovoru (interview). Rozhovor vycházel ze základních orientačních otázek, vztahujících se $\mathrm{k}$ TA v rámci školy: a) Jaká je pro tebe školní TV?, b) Je něco, co bys na TV změnil/a ?, c) Navštěvuješ ve škole některý ze sportovních kroužků?, d) Pokud ano/ne, tak proč?, e) Navštěvuješ mimo školu nějaký sportovní kroužek?

\section{Preference sportovních aktivit}

Preference sportovních aktivit participantů byly zjištovány metodou párového srovnávání(Dvořáčková, 2007; Spurná, 2008). Pro párové srovnávání bylo použito 10 vybraných paralympijských sportů spárovaných do 45 různých dvojic. Participanti pak měli vybrat $\mathrm{z}$ každé dvojice jednu sportovní disciplínu, které by dali přednost $\mathrm{v}$ rámci vlastní účasti. Postupným vyřazováním jednotlivých sportů $\mathrm{z}$ každé dvojice bylo možné získat skóre nejvíce preferovaných sportovních disciplín u každého participanta.

\section{Volný čas a volnočasové aktivity participantů}

Pro získání informací o množství volného času a charakteru volnočasových aktivit participantů byla použita metoda týdenního časového snímku (TČS). Participantům byl předán formulář TČS s př̀iděleným seznamem aktivit, do kterého každý žák zapisoval činnosti, které provozoval, a čas, který jim věnoval. TČS byl realizován po dobu jednoho týdne v květnu 2008. Časové údaje o jednotlivých aktivitách byly vyhodnoceny a zformulovány do přehledných tabulek, ze kterých je snadné referovat potřebné informace o náplni volného času sledovaného souboru. Kvantitativní hodnoty TČS jsme doplnili opět metodou rozhovoru. Otázky byly směřovány na jeden $z$ hlavních faktorů ovlivňující výběr volnočasových aktivit našich participantů, kterým je rodina a způsob, jakým tráví volný čas. Další otázky byly zaměřeny na charakter TA ve volném čase participantů. Podoba kladených otázek byla následující: a) S kým trávíš nejvíc svého volného času? b) Jaký charakter mají aktivity ve volném čase, který trávíš se svou rodinou? c) Věnuješ se ve svém volném čase nějakým TA? d) Pokud ne, tak proč? e) Věnují se tvoji rodiče ve volném čase nějaké $\mathrm{TA}$ ?

\section{VÝSLEDKY}

\section{Popis podmínek školní TV a sportovních kroužků v rámci školy}

ZŠ a SŠ Credo Olomouc, o.p.s, zajištuje vzdělávání žáků s vícenásobným postižením. Jedná se převážně o žáky s různými formami DMO, tedy žáky, kteří jsou na různých stupních pohybového vývoje a s různými možnostmi mobility. Tělesná výchova (TV) pro žáky ZŠ a SŠ Credo probíhá v rozsahu 2 vyučovacích hodin týdně. Výuka je realizována bud' ve vnitřním prostoru tělocvičny (cvičebny) nebo na venkovním hřišti v areálu školy. $V$ obou př́padech se jedná o prostory, které svou velikostí i vybavením nevyhovují klasickým potřebám školní TV. Při realizaci TV se vychází z Rámcového vzdělávacího programu pro základní vzdělávání (RVP ZV) a z přílohy Rámcového vzdělávacího programu pro základní vzdělávání upravující vzdělávání žáků s lehkým mentálním postižením (RVP ZV-LMP). Vzhledem $\mathrm{k}$ pohybovým možnostem žáků s DMO a jinými pohybovými vadami je tento plán upravován podle jejich potřeb. Učitelka TV má vypracovaný vlastní roční tematický plán, který vychází jak z RVP, tak z jejích zkušeností s žáky. TV ve všech ročnících vyučuje učitelka s aprobací aplikovaná tělesná výchova. V hodinách TV se respektuje princip zapojení všech žáků do hodin TV a využívá se aplikovaných pohy- 
bových aktivit a přizpůsobených sportovních her. V rámci školní TV probíhá i výuka plavání vymezená jednou hodinou týdně realizovanou na plaveckém stadionu v Olomouci.

K zájmovým TA, které škola žákům nabízí, patří sportovní kroužek a sportovní kroužek-Boccia. Obsah sportovního kroužku tvoří především přizpůsobené TA s využitím tradičního i netradičního náčiní, přizpo̊sobené sportovní hry a psychomotorické hry. Sportovní kroužek-Boccia je svým obsahem zaměřený převážně na trénink sportovní hry boccia. Oba sportovní kroužky se konají jednou týdně v prostorách cvičebny či venkovního hřiště v areálu ZŠ a SŠ Credo.

\section{Názory klientů na školní TA}

K otázce hodnotící školní TV se všichni participanti vyjádřili kladně. Na hodiny TV se těší a to, co v tělesné výchově dělají, je baví. Z činností, které participanti nejčastěji citovali jako zábavné, byly přizpůsobené sportovní hry (boccia, kuželky, florbal a stolní tenis), závodivé štafetové hry, hry s míči a plavání. U otázky: „Je něco, co bys na TV změnil/a?“ je nutné zohlednit fakt, že participanti nemají možnost srovnání s jinými podobami TV. Odpovědi byly bud’ že neví, nebo že by nezměnili nic.

Prostřednictvím otázek zaměřených na účast participantů $\mathrm{v}$ zájmových sportovních kroužcích v rámci ZŠ a SŠ Credo bylo zjištěno, že sportovní kroužky navštěvují žáci jak ze skupiny „chodících“, tak i „Vozíčkářu“u (tab. 1). Jako zajímavá se jeví především rozdílnost v typu sportovního kroužku, který si členové jednotlivých skupin zvolili. U žáků ze skupiny „,vozíčkáři“ šlo jednoznačně o sportovní kroužekBoccia, ve kterém se participanti cítili více kompetentní než při činnostech v rámci sportovního kroužku. U všech participantů, kteří navštěvují některý ze sportovních kroužků, byly hlavními důvody jejich účasti, že je tyto činnosti baví, možnost setkávat se s kamarády a možnost získávat lepší výsledky v soutěžích a závodech v rámci různých sportovních dnů či akcí zprostředkovávaných školou. Důvody, proč dotazovaní participanti nenavštěvují žádný ze školních sportovních kroužků, byly celkový nezájem o TA a také nedostatek času k jejich provozování. U participantů ze skupiny „vozíčkáři“ byl navíc jako další důvod uváděn jejich špatný zdravotní stav, který jim brání účastnit se TA.

Tab. 1. Účast participantů v zájmových sportovních kroužcích ZŠ a SŠ Credo

\begin{tabular}{|c|c|c|c|c|c|c|}
\hline & \multicolumn{2}{|c|}{ chodící } & \multicolumn{2}{c|}{ vozíčkáři } & \multicolumn{2}{c|}{ celkem } \\
\hline & počet & $\%$ & počet & $\%$ & počet & $\%$ \\
\hline ano & 4 (2-sportovní k. + boccia, 2-boccia) & 80 & 3 (3-boccia) & 50 & 7 & 64 \\
\hline ne & 1 & 20 & 3 & 50 & 4 & 36 \\
\hline suma & 5 & 100 & 6 & 100 & 11 & 100 \\
\hline
\end{tabular}

$\mathrm{Na}$ otázku, jestli někdo navštěvuje mimoškolní sportovní kroužek, odpověděli všichni dotazovaní záporně. Hlavním důvodem u těch, kteří by př́ípadně měli zájem nějaký sportovní kroužek ve svém volném čase navštěvovat, bylo, že o žádném vhodném sportovním kroužku neví.

\section{Preference sportovních aktivit}

Párovým srovnáváním deseti vybraných sportů (lukostřelba, plavání, florbal, atletika, badminton, boccia, rugby, kuželky, basketbal, volejbal) byly získány informace o sportovních preferencích jednotlivých participantů (tab. 2). U participantů ze skupiny „vozíčkáři“ byly mezi nejvíce preferovanými 1 . boccia, 2. kuželky, 3. plavání a 4. florbal, u členů ze skupiny „chodící“ to byly 1. kuželky, 2. plavání, 3. badminton a 4. boccia. Se všemi uvedenými sportovními disciplínami mají participanti vlastní zkušenosti a také patří mezi velmi časté TA zařazované do školní TV a školních sportovních kroužků.

$\mathrm{K}$ nejméně preferovaným sportovním disciplínám u všech participantů patři basketbal, atletika a volejbal (tab.2). Tyto sporty se $\mathrm{v}$ rámci školních TA, vzhledem $\mathrm{k}$ materiálnímu a prostorovému vybavení školy, realizují pouze omezeně. $V$ př́padě ragby se u participantů jednalo o sportovní disciplínu, s níž neměli žádné zkušenosti a většina $\mathrm{z}$ nich tento sport neznala. Vzhledem $\mathrm{k}$ uvedeným údajům lze usuzo- 
vat, že preference sportovních disciplín je z velké části ovlivněna vlastní zkušeností participantů s danou sportovní aktivitou.

Tabulka 2. Preference sportovních aktivit probandů dle metody párového srovnávání

\begin{tabular}{|c|c|c|c|c|c|c|c|c|c|c|c|}
\hline klient & \multicolumn{9}{|c|}{ Sportovní disciplína } \\
\hline & lukostřelba & plavání & florbal & atletika & badminton & boccia & rugby & kuželky & basketbal & volejbal \\
\hline Chodící & & & & & & & & & & \\
\hline MK & 0 & 9 & 6 & 3 & 4 & 4 & 4 & 8 & 6 & 1 \\
\hline TM & 4 & 8 & 2 & 2 & 7 & 2 & 0 & 9 & 6 & 5 \\
\hline ZL & 4 & 6 & 7 & 3 & 5 & 9 & 0 & 8 & 1 & 2 \\
\hline ED & 6 & 7 & 2 & 5 & 5 & 7 & 0 & 9 & 1 & 3 \\
\hline LD & 4 & 9 & 3 & 6 & 8 & 5 & 0 & 7 & 2 & 1 \\
\hline$\Sigma$ & 18 & 39 & 20 & 19 & 29 & 27 & 4 & 41 & 16 & 12 \\
\hline Pořadí & 7. & 2. & 5. & 6. & 3. & 4. & 10. & 1. & 8. & 9. \\
\hline Vozíćkáŕi & & & & & & & & & & \\
\hline KŽ & 4 & 9 & 1 & 3 & 4 & 7 & 0 & 8 & 5 & 3 \\
\hline SB & 7 & 1 & 5 & 6 & 2 & 9 & 3 & 8 & 4 & 0 \\
\hline AV & 5 & 9 & 7 & 4 & 3 & 7 & 0 & 7 & 2 & 1 \\
\hline RR & 5 & 5 & 7 & 3 & 0 & 9 & 2 & 8 & 5 & 1 \\
\hline MK & 2 & 9 & 6 & 1 & 0 & 7 & 4 & 8 & 5 & 3 \\
\hline PT & 7 & 8 & 5 & 1 & 4 & 9 & 1 & 6 & 1 & 3 \\
\hline$\Sigma$ & 30 & 41 & 31 & 18 & 13 & 48 & 10 & 45 & 22 & 11 \\
\hline Pořadí & 5. & 3. & 4. & 7. & 8. & 1. & 10. & 2. & 6. & 9. \\
\hline Celk. $\Sigma$ & 48 & 80 & 51 & 37 & 42 & 75 & 14 & 86 & 38 & 23 \\
\hline Celk. pǒráín & 5. & 2. & 4. & 8. & 6. & 3. & 10. & 1. & 7. & 9. \\
\hline & & & & & & & & & & \\
\hline
\end{tabular}

\section{Volný čas a volnočasové aktivity participantů}

Technikou TČS jsme získali informace o množství volného času participantů (tab. 3) a také o způsobu, jak svůj volný čas nejčastěji tráví (tab. 4).

Tab. 3. Průměrný počet hodin strávený ve čtyřech orientačních oblastech činností participantů

\begin{tabular}{|c|c|c|c|}
\hline \multirow{2}{*}{4 orientační oblasti činností } & \multicolumn{3}{|c|}{ Průměrný počet hodin denně (týdně) } \\
\cline { 2 - 4 } & chodící & vozíčkáři & celkem \\
\hline uspokojování biologických potřeb & $1,9(13,3)$ & $2,5(17,5)$ & $2,2(15,4)$ \\
\hline domácí rehabilitace & & $1,0(7,0)$ & $1,0(7,0)$ \\
\hline čas strávený ve škole & $6,3^{\star}(31,5)^{\star}$ & $6,5^{\star}(32,5)^{\star}$ & $6,4^{\star}(32)^{\star}$ \\
\hline volný čas & $7,7(53,9)$ & $6,4(44,8)$ & $7,1(49,7)$ \\
\hline
\end{tabular}

$\left.{ }^{\star}\right)$ pouze pracovní dny

Z tabulky 3 je patrné, že v průměru větším množstvím volného času disponují participanti ze skupiny „chodících“ (7,7 hodin denně). U skupiny „vozíčkářư “ je tedy nutné zohlednit průměrně větší množství času stráveného v rámci uspokojování biologických potřeb (čas věnovaný jídlu, oblékání se, osobní hygiena a další sebeobslužné úkony) a navíc čas strávený v rámci domácího rehabilitačního cvičení. 
Tab. 4. Náplň volného času participantů v průměrném počtu hodin za týden

\begin{tabular}{|c|c|c|c|c|c|c|}
\hline Volnočasové aktivity & chodící & $\begin{array}{c}\text { pořadí } \\
\text { aktivit }\end{array}$ & vozíčkáři & $\begin{array}{c}\text { pořadí } \\
\text { aktivit }\end{array}$ & celkem & $\begin{array}{c}\text { pořadí } \\
\text { aktivit }\end{array}$ \\
\hline sledování televize & 14,0 & 1. & 17,2 & 1. & 15,6 & 1. \\
\hline činnosti na PC & 3,5 & 4. & 6,4 & 3. & 4,9 & 4. \\
\hline četba knih, časopisů & 2,6 & 5. & 1,5 & 6. & 2,1 & 6. \\
\hline poslech hudby, rádio & 0,9 & 8. & 6,2 & 5. & 3,6 & 5. \\
\hline $\begin{array}{c}\text { procházky a aktiv- } \\
\text { ní pobyt venku, výlety }\end{array}$ & 6,7 & 2. & 6,3 & 4. & 6,5 & 2. \\
\hline umělecké činnosti & 1,3 & 7. & 0,4 & 8. & 0,8 & 8. \\
\hline povídání si se známými, s přáteli & 5,3 & 3. & 6,6 & 2. & 6,0 & 3. \\
\hline společenské hry & 1,4 & 6. & 1,0 & 7. & 1,2 & 7. \\
\hline cvičení, tělocvičné aktivity & 0,3 & 9. & 0,1 & 9. & 0,2 & 9 \\
\hline
\end{tabular}

Z tabulky 4 vyplývá, že nejvíce volného času jak členové ze skupiny „vozíčkáři“, tak i členové ze skupiny „chodící“ stráví sledováním televize. $V$ průměru tato činnost u všech probandů zabere 15,6 hodin týdně, což představuje $31,4 \% \mathrm{z}$ celkového volného času probandů. Obě skupiny se shodují i v činnosti, které $\mathrm{v}$ průběhu týdne věnují nejméně času, a tím jsou právě TA.

Na základě otázky, s kým tráví participanti nejvíce volného času, jsme získali jednoznačnou odpověd, že s rodinou nebo jejími jednotlivými členy. Mezi nejčastější aktivity, kterými tráví volný čas se svou rodinou, byly dotazovanými uváděny sledování televize, povídání si, procházky či výlety a hry na počítači. Shodnost volnočasových aktivit probandủ, které zabírají nejvíce jejich volného času, a volnočasových aktivit konaných $\mathrm{v}$ rámci rodiny je zde patrná.

TA věnují participanti v týdnu nejméně svého volného času ( 0,2 hodin týdně). Důvody, které dotazovaní uváděli, byly preference pasivnějších volnočasových aktivit (sledování televize, poslech hudby či hry na počítači) a také fakt, že nemají, s kým by se TA věnovali. Na otázku, zdali se rodiče dotazovaných žáků věnují ve volném čase nějaké $T A$, odpověděli pouze tři participanti kladně. $V$ prvním případě se jednalo o domácí cvičení pro zlepšení kondice (posilovací cviky a protažení) a v druhém př́ípadě se rodiče věnovali turistice, jízdě na kole a fotbalu. $V$ obou př́ipadech do těchto aktivit zapojovali i naše probandy. Ve třetím prrípadě se jednalo o otce, který chodí hrát tenis, ovšem do této TA zapojuje pouze zdravého sourozence dotazovaného probanda.

\section{DISKUZE}

Z výsledků provedené studie je patrný význam organizovaných forem TA jako je školní TV a školní sportovní kroužky, které u většiny žáků představují jediné TA v průběhu celého dne. S podobnými výsledky se můžeme setkat např́klad i v rámci modifikace kanadské studie „Fitness Survey“ zaměřené na TA mládeže s TP (Chien-Yu Pan, Frey, Bar-Or \& Longmuir, 2005). Z dotazovaných participantů $75 \%$ dětí a $66 \%$ adolescentů uvádělo školu jako nejčastější prostředí, ve kterém realizují TA. Zásadní vliv na kvalitu realizovaných TA mají materiální vybavení a personální zajištění školy. Ovšem ne vždy je škola schopna poskytnout vhodné prostorové a materiální vybavení pro výuku ATV. O to větší význam spadá na roli učitele či realizátora TA žáků s TP. ZŠ a SŠ Credo navštěvují převážně žáci s různými typy DMO, tedy žáci s různým stupněm pohybového omezení. Chce-li učitel TV zapojit do TA všechny žáky, vyžaduje to u něj jistou způsobilost k realizaci aplikovaných pohybových aktivit (APA). Jako rozhodující kompetence potřebné pro organizování TA žáků s TP Válková \& Morisbak (2006) uvádějí kreativitu, znalosti z oblasti modifikací TA a znalosti TA, které chceme přizpůsobovat. $Z$ výsledků námi provedené studie vyplývá, že nejvíce volného času tráví participanti se svou rodinou. Volba a způsob trávení volného času participantů se výrazně odrážely od způsobu trávení volného času jejich rodičů. Školní výchovné prostředí a rodina tak patři k významným činitelům majícím vliv na utváření a upevňování pozitiv- 
ního vztahu ke sportovním a jiným TA. Neopomenutelnou roli tedy hrají také vzájemná komunikace mezi školou a rodinou žáka s TP. Na význam a prospěch interakce těchto dvou institucí v kontextu TA ve své práci poukazují Seaman, DePauw, Morton a Omoto (2003). K dalším důležitým faktorům majícím vliv na participaci v TA patří úroveň mobility, která je úzce spojena s pocitem kompetentnosti žáka s DMO v daných TA (Čurdová, 2005). Na tento fakt může v naší studii poukazovat jednoznačný výběr zájmového sportovního kroužku-Boccia u participantů ze skupiny „,vozíčkáři“, ve kterém se tito participanti cítili více kompetentní než při činnostech v rámci sportovního kroužku. Nabídnout širokou škálu TA a umožnit v nich úspěšnou účast každému žákovi by mělo být hlavním cílem každého realizátora sportovních i jiných TA. Nemalou roli v participaci žáků s TP v TA měla i informovanost v této oblasti. Hlavním důvodem, proč nikdo z respondentů nenavštěvuje mimoškolní sportovní kroužek, byla právě neznalost jakéhokoliv jiného sportovního kroužku. Znalost a neznalost jednotlivých sportovních disciplín se také do jisté míry odrážela v preferencích nabízených sportovních disciplín. Žáci preferovali takové sportovní disciplíny, s nimiž mají vlastní zkušenosti a často se jim ve školní TV či školních sportovních kroužcích věnují.

\section{ZÁVĚR}

Míra spontánních pohybových aktivit u dětí s DMO bývá mnohdy omezována fyzickými bariérami okolního prostředí a absencí organizovaných tělocvičných aktivit (TA) ve volném čase. Organizované formy TA jako je školní TV a školní sportovní kroužky mohou pro žáky s TP (DMO) představovat jediné prostředí, ve kterém jsou realizovány TA. Škola může hrát důležitou roli v utváření kladného vztahu žáků s DMO k TA i jejich aktivního životního stylu. Při plánování a realizaci TA žáků s DMO je nutné vycházet $\mathrm{z}$ řady faktorů majících vliv na jejich kvalitní průběh. K hlavním faktorům lze zařadit materiální a personální podmínky výuky. Podle vyhlášky 73/2005 o vzdělávání dětí a žáků se speciálními vzdělávacími potřebami a žáků mimořádně nadaných je ke vzdělávání žáků s TP nutné zajistit taková podpůrná opatření, která umožní absolvovat výuku (tedy i výuku TV). „Podpůrnými opatřeními se rozumí využití speciálních metod, postupů, forem a prostředků vzdělávání, kompenzačních, rehabilitačních a učebních pomůcek, speciálních učebnic a didaktických materiálů, zařazení speciálně pedagogické péče, poskytování pedagogicko-psychologických služeb, zajištění služeb asistenta pedagoga, snížení počtu žáků ve třídě... nebo jiná úprava zohledňující speciální vzdělávací potřeby žáka." (Vyhláška 73/2005, \$1.). Pro účely ATV lze z podpůrných opatření využít sportovně kompenzační pomůcky, speciální metody a postupy z oblasti APA a pedagogické podpory z řad odborníků aplikovaných pohybových aktivit. Dalším z faktorů ovlivňující průběh TA i samotný prrístup žáka $\mathrm{k}$ dané TA je úroveň jeho pohybových schopností a úroveň jeho mobility, které jsou blízce spojeny s pocity kompetentnosti žáka s DMO k vybraným TA. Každý jedinec se obvykle více zajímá o činnost, v níž má relativně dobré výsledky, než o činnost, v níž je v důsledku chabých předpokladů málo úspěšný. Pocit vlastní kompetence je založen na osobní zkušenosti se zvládáním určitých dovedností (činností) a k jeho zvýšení přispívá zážitek mistrovství (mastery). Proto pocit kompetentnosti lze získat jen na základě praktického provádění činnosti, $v$ př́ípadě, že je nám umožněno prožít pocit úspěchu, např́íklad z osvojení si nějaké pohybové dovednosti, pravidel sportovní hry či disciplíny apod. (Čurdová, 2002). Za důležitý faktor ovlivňující participaci žákủ s DMO na TA lze tedy považovat i informovanost žáků v oblasti TA, která se v př́ípadě našeho výzkumu odrážela ve sportovních preferencích participantů. Dotazovaní žáci preferovali především ty sportovní disciplíny, se kterými měli vlastní zkušenost $\mathrm{v}$ rámci školní TV a školních sportovních kroužků. Dostatečná informovanost v oblasti TA žáků s DMO je rozhodující jak pro samotné žáky, tak zejména pro učitele ATV a rodinu žáka s DMO. Zde opět sehrávají důležitou roli převážně odborníci z oblasti APA, kteří by měli být kompetentní poskytnout veškeré potřebné informace a nabídnout široké spektrum modifikovaných TA, které umožní zapojit i jedince s těžkým tělesným postižením. 


\section{Literatura:}

ČESKÁ FEDERACE SPORTOVCŮ S CENTRÁLNÍMI PORUCHAMI HYBNOSTI SPASTIC HANDICAP. Sdružené tělovýchovné jednoty a kluby. Retrieved 16.11.2009 from the World Wide Web: http://www.handicapsports.cz/index jednoty.htm

CHIEN-YU, P., GEORGIA, C. F., BAR-OR, O., LONGMUIR, P. Concordance of Physical Activity among Parents and Youth with Physical disabilities. Journal of Developmental and Physical Disabilities, 2005, vol. 17, No. 4, pp. 395-407.

CENRUM APA. Retrieved 2.2. 2010 from the World Wide Web: http://www.apa.upol.cz/web/

ČURDOVÁ, J. Volnočasové pohybové aktivity osob s postižením. Volný čas a jeho současné problémy. Sborník př́spěvkư přednesených na vědeckém symposiu v Olomouci ve dnech 20. a 21. května 2002. Olomouc: Hanex, 2002, p. 10-118.. ISBN 80-85783-37-1.

ČURDOVÁ, J. Hodnocení sebevědomí u dětí s dětskou mozkovou obrnou. Disertační práce, Univerzita Palackého, Fakulta tělesné kultury, Olomouc, 2005.

DVOŘÁČKOVÁ, Z. Školní tělesná výchova v 7. ročníku základní školy při ústavu sociální péče pro tělesně postiženou mládež Kociánka v Brně. Diplomová práce, Univerzita Palackého, Fakuta tělesné kultury, Olomouc, 2007.

HRONCOVÁ, J. Možnosti primárnej prevencie sociálno-patologických jevov u detí a mládeže vo volnom čase. Mládež a volný čas. Hradec Králové: Gaudeamus. 2000, pp. 141-145.

KALVACH, Z., ET AL. Geriatrie a gerontologie. Praha: Grada, 2004. ISBN 80-247-0548-6.

KUDLÁČEK, M., A KOL. Aplikované pohybové aktivity pro osoby s tělesným postižením. Olomouc: Univerzita Palackého, 2007. ISBN 978-80-244-1655-7.

KUDLÁČEK, M. Podpora integrace žáků s tělesným postižením do hodin běžné tělesné výchovy. In M. Kudláček, T. Vyskočil (Ed.), Integrace - jiná cesta II. Olomouc: Univerzita Palackého, 2008, pp. 42-47. ISBN 978-80-244-2029-5.

KUDLÁČEK, M., JEŠINA, O., ŠTĚRBOVÁ, D. Integrace žáků s tělesným postižním v kontextu školní tělesné výchovy. Speciální pedagogika, 2008, roč. 3, p. 232-239. ISSN 1211-2720.

MACHOVÁ, I. Sport jako prostředek integrace. In M. Kudláček, T. Vyskočil (Ed.), Integrace - jiná cesta II. Olomouc: Univerzita Palackého, 2008, pp. 42-47. ISBN 978-80-244-2029-5.

MOLIK, B. Disability groups and adaptation strategies. In: In count me in: A guide to inclusive Physical activity, Sport and Leisure for a children with a disability. Chapter 4: Adaptation Strategies. Belgium: Education and culture, 2006, pp. 33-60.

RENOTIÉROVÁ, M. Speciální pedagogika osob s postižením hybnosti. In: M. Renotiérová, L. Ludíková (Ed.), Speciální pedagogika. Olomouc: Univerzita Palackého, 2006, pp. 9-30. ISBM 80-244-1475-9.

SEAMAN, J., A., ET AL. Connections and Transitions. In: Chapter 14. In Making Connections. From Theory to Practice in Adapted Physical Education. United States of America: Holcomb Hathaway, 2003, pp. 331-348. ISBN 1-890871-44-3.

SPURNÁ, M. Tělocvičné aktivity osob s dětskou mozkovou obrnou při o.s. Jitro v Olomouci. Diplomová práce, Univerzita Palackého, Fakulta tělesné kultury, Olomouc, 2008.

VÁLKOVÁ, H., MORISBAK, I. What is adapted Physical activity? In: Chapter 3: Understanding Adapted Physical Activity and Inclusion. In: Count me in: A guide to inclusive Physical Activity, Sport and Leisure for Children with a Disability. Belgium: Education and culture, 2006, pp. 31-58.

Vyhláška MŠMT č. 73/2005 Sb., o vzdělávání dětí, žáků a studentů se speciálními vzdělávacími potřebami a dětí, žáků a studentů mimořádně nadaných.

WITTMANOVÁ, J. Boccia. In: M. Kudláček a kol. Aplikované pohybové aktivity pro osoby s tělesným postižením. Olomouc: Univerzita Palackého, 2007, pp. 72-81. ISBN 978-80-244-1655-7

WORLD HEALTH ORGANISATION. International Classification of Functioning, Disability and Health. Retrieved 16.11. 2009 from the World Wide Web: http://www.who.int/classifications/icf/en/ 